HEROES AND MARTYRS OF QUALITY AND SAFETY

\title{
Avedis Donabedian: father of quality assurance and poet
}

\author{
M Best, D Neuhauser
}

Qual Saf Health Care 2004;13:472-473. doi: 10.1136/qshc.2004.012591

A vedis Donabedian was born in Beirut, Lebanon on 7 January 1919. As a child he moved to a small town near Jerusalem in Palestine (now Israel) after his family fled the Armenian holocaust. However, in Palestine he experienced the social turmoil of that region. Although a Christian, he had Jewish, Arab, and Christian friends as he was growing up in Palestine. ${ }^{1}$ At the interpersonal level he was able to circumvent social and political obstacles.

Years later Donabedian attended the American University of Beirut where he received a BA degree in 1940 and an MD degree in 1944. He served as a general practitioner physician in Jerusalem and Beirut until 1954 when he moved to Boston. In 1955 he graduated from the Harvard School of Public Health with an MPH degree (magna cum laude). He taught preventive medicine at the New York Medical College from 1957 to 1961. The School of Public Health at The University of Michigan recruited him in 1961, and he remained there for 28 years. In 1979 he was honored as the Nathan Sinai Distinguished Professor of Public Health at the University of Michigan in recognition of his contributions in public health. He retired in 1989 but continued to serve as emeritus professor until his death on 9 November 2000 after a 28 year battle with prostate cancer.

\section{THE SCHOLAR}

In 1969 Donabedian received the Dean Conley Award by the American College of Hospital Administrators and in 1976 he was presented with the George Welch Medal by the American Medical Association. He was one of the original members inaugurated into the Institute of Medicine of the National Academy of Sciences. He was an honorary member of the National Academy of Mexico and the Royal College of General Practitioners of the United Kingdom (University Archives and Records Program, Bentley Historical Library, University of Michigan, USA). Foundations, libraries, and research centers in Spain, Argentina, Italy, Israel and Mexico are named after him.

As Donabedian received the Baxter American Foundation Health Services Research Prize in 1986, he stated: "In all my work I have tried to embody the passionate conviction that the world of ideas and the world of action are not separate, as some would have us think, but inseparable parts of each other. Ideas, in particular, are the truly potent forces that shape the tangible world".

Donabedian understood health care as a system. He stated: "People have a big problem understanding the relationship between quality and systems". "System management doesn't get taught in medical school or nursing school". "There's lip service to quality and, goodness knows, propaganda, but real commitment is in short supply". "Systems awareness and systems design are important for health professionals, but are not enough. They are enabling mechanisms only. It is the ethical dimension of individuals that is essential to a system's success. Ultimately, the secret of quality is love. You have to love your patient, you have to love your profession, you have to love your God. If you have love, you can then work backward to monitor and improve the system.."1 Donabedian wrote 11 books and over 100 articles. His 1966 article
"Evaluating the quality of medical care" published in the Milbank Memorial Fund Quarterly was where he divided quality of health care measures into structure, process and outcome. ${ }^{2}$ This has become the best known framework in health services research. It has the power of a great idea.

This 1966 issue of Milbank Quarterly reviews the state of the entire field of medical care research (today this would be called health services research). In the opening article Odin Anderson despaired that this research had not proactively influenced public policy. ${ }^{3}$ Politicians made decisions unsupported by evidence. He hoped for a future where research evidence would be used prospectively to guide policy.

Donabedian and Anderson propose two different ideas about influence- the power of ideas and the power of timely data. John Maynard Keynes (1883-1946) sided with Donabedian when he wrote "Practical men who believe themselves to be quite exempt from any intellectual influences are usually the slaves of some defunct economist. ... It is ideas not vested interests which are dangerous for good or evil."

\section{Box 1 Correspondence with Avedis Donabedian}

August 8, 1997

Dear Duncan

What a pleasure to hear from you after so long a silence especially when, in your letter, you say you are interested in my poetry. Alas, there is no book, nor is there likely to be. My poetry is distinctly out of fashion (steeped as it is in antiquated romanticism) and moreover of not sufficiently advanced virtuosity. Mainly, I have written for myself, not so much for my own pleasure, as a need to deal with (perhaps come to terms with) somewhat painful things in my life.

I have, however, assembled a selection of my poems in two little pamphlets which I have shared with close friends. I am delighted to be able to send these.

Yours,

Avedis

Sept 5, 1997

Dear Avedis,

We will all be known for our scholarship in print. This literature gives no hint that there are real human beings involved in this enterprise, people who feel sad, who love, who take pleasure in watching a bird and who observe the world through the lens of emotions. Your "Recollections" break through this boundary between our austere professional work and our warm human state. In this way you do us all a great favor and service. You say to future generations that our studied search for better health care was carried out by feeling, passionate men and women.

This is why I am so pleased and why I thank you.

Sincerely,

Duncan 


\section{Box 2 Two poems by Avedis Donabedian*}

Encounter

I dreamt I met you

One morning, quite by chance,

In an avenue of autumn trees.

How sad, you said,

That you had never loved me,

That you were only my friend.

How sad, I said

That I had only loved you,

That I was never your friend.

Again we passed each other,

Sorrowing

That a friend could not be lover,

Nor lover friend.

Los Molinos Spain, December 7, 1992

Donabedian A. "Recollections of Fugitive Loves". Selected verses 1940-1994 (unpublished)

Daisies in winter

It is deep winter now,

And deep the snow

On winter's desolation

Wasteland of white

Torments my eyes, and bids

My sorrow flow.

Deep in my heart

There is your summer now,

To set my meadows greening.

Green-garlanded

Daisies are flecks of snow,

Their hearts aglow.

Deep under snow

It is dark winter now,

But in your sun

Winter shades into summer,

All seasons one.

Ann Arbor, March 2 and 18, 1995

Donabedian A. "A Second Supplement to Recollections of Fugitive Loves". Selected verses 1995 and 1996 (unpublished)

*Published with permission from Haig Donabedian MD.
Donabedian's three volume book set on the "Explorations in quality assessment and monitoring" (1980-1985) is a monumental contribution to healthcare quality. ${ }^{5} \mathrm{He}$ articulated his seven pillars of quality as being: efficacy, efficiency, optimality, acceptability, legitimacy, equity, and cost. His contributions to healthcare quality include addressing issues such as access to health care, measuring and evaluating healthcare quality, completeness and accuracy of medical records, observer bias, patient satisfaction, and cultural preferences in health care.

\section{THE POET}

Professor Donabedian was a poet, passionate about literature, and a fluent reader in six languages. It was not his nature to confront people or to buck scientific trends. His strategic approach was to establish connections with "friendship and solidarity among all the different students he had throughout the world and to build bridges of understanding and appreciation among people and countries." ${ }^{\prime 6}$ He profoundly touched the lives of many people. Julio Frenk wrote: "For the many dimensions of his generosity, everyone who knew Avedis Donabedian is indebted to him. But to owe something to this extraordinary man is a paradoxical debt, because it has forever enriched our lives." ${ }^{17}$ Donabedian wrote poetry throughout his life. Near the time of his death he remarked: "It is the poetry that tells the most about who I am". ${ }^{1}$

A letter from Donabedian to one of the authors (DN) with a letter in reply are shown in box 1 and two representative poems by Donabedian, the first written when he was 73 years old, are shown in box 2. All are previously unpublished.

\section{Authors' affiliations}

M Best, D Neuhauser, Department of Epidemiology and Biostatistics, Case School of Medicine, Case Western Reserve University, Cleveland, $\mathrm{OH}$ 44106-4945, USA

Correspondence to: Professor D Neuhauser, Department of Epidemiology and Biostatistics, Case School of Medicine, Case Western Reserve University, Cleveland, OH 44106-4945, USA; dvn@case.edu

\section{REFERENCES}

1 Mullan F. A Founder of quality assessment encounters a troubled system firsthand. Health Aff 2001;20:137-41.

2 Donabedian A. Evaluating the quality of medical care. Milbank Memorial Fund Quarterly 1966;44:166-206.

3 Anderson $\mathrm{O}$. Influence of social and economic research on public policy in the health field. Milbank Memorial Fund Quarterly 1966;44:11-48.

4 Keynes JM. The general theory of employment, interest and money (1936). Cited in Bartlett J. Familiar quotations, 14th ed. Boston, Mass: Little, Brown 1968:977.

5 Donabedian A. Explorations in quality assessment and monitoring. Vol. I. The definition of quality and approaches to its assessment, 1980; Vol. II. The criteria and standards of quality, 1982; Vol. III. The methods and findings of quality assessment and monitoring: an illustrated analysis. Ann Arbor: Health Administration Press, 1985

6 Suñol R. Avedis Donabedian. Int J Qual Health Care 2000;12:451-4.

7 Frenk J. Obituary: Avedis Donabedian. Bull WHO 2000;78:1475. 